\title{
Pardoning and Mercy
}

\author{
Jonathan Burnside*
}

\begin{abstract}
"Dieu me pardonnera', said the dying Heine, "c 'est son métier. " Legal philosophers and criminologists would ask whether it is not also the job of some secular authority. In the light of recent discussion about the nature of forgiveness and mercy, ' we consider what sorts of reasoning might justify pardoning and mercy within the criminal justice system.
\end{abstract}

\section{Pardoning}

'Pardoning' is a loose word which needs to be considered in both its legal and colloquial sense.

First, to consider what pardoning means in its legal sense. On the view that the meaning of law is interpretative, we can identify several interpretations of this legal concept. In choosing the best interpretation we shall be following the two-stage test proposed by Ronald Dworkin in Law's Empire. ${ }^{2}$ This will involve testing each interpretation to see if it satisfies the twin constraints on 'fit' and 'appeal'. Thus the correct interpretation will be the one which provides an accurate description of current legal practice and which also presents the legal concept of pardon in its most morally appealing light.

The first interpretation draws on judicial utterances to explain what pardoning means. According to the judiciary, forgiveness is central:

"the essence of a pardon is the forgiveness of something that has been done." 3

*Doctoral Student, University of Liverpool. I am very grateful to Dr. N. E. Simmonds, Prof. N. Walker and Mr. A. J. Weir for their comments on earlier drafts of this essay. Any mistakes that remain are the sole fault of the author.

1. See Jeffrie G. Murphy and Jean Hampton, Forgiveness and Mercy (Cambridge, 1988); Nigel Walker. Why Punish? (Oxford, 1991); Ross Harrison, "The Equality of Mercy" in Hyman Gross and Ross Harrison (eds.), Jurisprudence: Cambridge Essays (Oxford, 1992) and N. E. Simmonds, Judgment and Mercy (forthcoming) Oxford Journal of Legal Studies.

2. Ronald Dworkin, Law's Empire (London, 1986).

3. R. v. Foster [1985] Q.B. 115, at p.117. 
Were it not for the first stage of the Dworkinian test one could be deceived into thinking this to be true. For the judicial interpretation of the meaning of pardon is not a happy fit with legal practice. The royal pardon is almost always reserved for cases where there is real doubt about the justice of the conviction. This is presumably why the existence of a 'scintilla of doubt' led only to a commutation of the death penalty. Then, as now, the Home Secretary will only grant a pardon if he is satisfied that the individual is innocent. Forgiveness cannot truly be at the heart of the legal pardon because, at the very least, forgiveness is always a response to harm that has been done. ${ }^{4}$ There is no sense in 'pardoning' someone for something they have not done. As Rolph writes:

"It is as though you or I, moved by the desire to knock a man down, carelessly knocked down the wrong one; and then, rather grudgingly helping him to his feet explained that we were prepared to consider conferring upon him . . . our pardon for being the wrong man." 5

Thus this interpretation of pardoning falls at the first hurdle. This does not necessarily mean that forgiveness has no part in the criminal justice system, but it means that if it does, the legal concept of pardon is not an example of it.

The second interpretation of the legal 'pardon' is offered by Rolph who sees it as a piece of "face-saving"' 6 on the part of the courts. He argues that since most countries share "a traditional belief that the courts represent God [or] judicial infallibility . . . failure in such a system is simply not to be spoken of." 7 Thus, although we are prepared to accept that mistakes are possible in a court of law, the process of correcting failures needs to be 'dressed up' by the use of such words as pardon.

This interpretation passes the 'constraint on fit' test by providing an accurate description of current legal practice. In no sense is the legal pardon to be formally taken as an acknowledgement that a mistake has been made. As Morris CJ puts it:

"[ the pardon] contains no notion that the man to whom the pardon is extended never did in fact commit the crime." 8

Even the payment of compensation is made ex gratia and, in the words of one Home Secretary, Major Gwilym Lloyd-George:

"it . . does not imply that there has been any fault or neglect on the part of the authorities."

4. Jean Hampton, "Forgiveness, Resentment and Hatred" in Jeffrie G. Murphy and Jean Hampton, Forgiveness and Mercy (Cambridge, 1988), p.40.

5. C.H. Rolph, The Queen's Pardon (London, 1978), p. 140.

6. lbid., p.l.

7. Ibid., p. 140 .

8. R. v. Cosgrove [1948]. Cited in R. v. Foster [1985] Q.B. 115 at p. 128.

9. C.H. Rolph, The Queen's Pardon (London, 1978), p.10. 
However, whilst this interpretation succeeds descriptively, it fails the second stage of the Dworkinian test since it does not present the concept in a morally appealing light.

Yet there is a third interpretation to be considered. By looking at its practical effects, the legal pardon can be seen as the remission of the legal consequences of an individual's conviction. This is a sounder interpretation than either of the preceding two. Unlike the first it can logically apply even where the accused man is innocent. It confines itself solely to the legal consequences of the conviction and it is thus no objection to claim that a man may be convicted for a crime of which he is innocent.

It also succeeds on both dimensions of interpretation by satisfying the constraints on fit and appeal.

First, it succeeds descriptively by providing an accurate description of current legal practice. The decision of the Court of Appeal in $R$. v. Foster (1985) is authority for the view that a pardon releases the individual from the legal consequences of the conviction but not from the conviction itself. ${ }^{10}$

Second, it succeeds prescriptively by presenting the legal pardon in its most morally appealing light. For on this interpretation, pardoning is to do with securing justice. Under the current separation of powers it is the métier of the judiciary to pronounce judgment on the individual and, where a punitive sentence is passed, for the Executive to carry it out. Pardoning may therefore be justified on the ground that one cannot expect the Executive to punish if it is satisfied that the individual is innocent. Pardoning is part of its job because punishment is part of its job. It may be argued that the reason why the Home Secretary cannot be required to punish a person he is convinced is innocent is because he owes a duty to some authority higher than the judiciary. Within the framework of secular authority one might want to call this justice.

This justification goes some way towards clearing up some of the misconceptions which have bedevilled writers on the subject. It is a standard criticism, which judges themselves have sometimes made, that the Queen's pardon removes "the consequences of a conviction, but does not assert that the person convicted was in fact innocent of the crime charged."'ll Yet on this justification of pardon, how can it do otherwise? The job of the judiciary is to pronounce upon the defendant's guilt; that of the Executive to carry out the judgment of the court. Where the Executive can no longer carry out its task, because of its need to secure justice, it must release the individual from the legal consequences of his conviction. But it cannot pronounce upon his guilt because it is not the proper organ to do so. Unless his record is reversed for error by the Criminal Division of the Court of Appeal, or unless he can promote a private Act of Parliament then, for legal purposes, he must be guilty. One judicial act may only be upset by another. It is not possible for the Crown to set aside a judgment of the court.

This same justification also disposes of arguments that pardoning is unjustified because it is a constitutional "anomaly" 12 as well as reasoning that it is wrong in 
principle to go outside the law to secure justice. ${ }^{13}$ As this justification of pardoning shows, there are occasions when it may be necessary to do exactly that.

So much, then, for the justification of pardoning as a legal concept. There is, however, another sense in which the word pardoning is used and with which it is often confused.

In colloquial terms a pardon is "the passing over of an offence without punishment." 14 Compared with its correct legal interpretation it is a very loose word which seems to straddle both mercy and forgiveness. In one sense, the colloquial 'pardon' may be seen as the practical expression of the characteristic of mercy. In another, it can just as easily be seen as a synonym for forgiveness. It could mean either but it cannot mean both for mercy and forgiveness are distinct terms. No doubt the question of which of the two the colloquial pardon most closely resembles is largely determined by context, but this is not so with the legal interpretation of pardon. To which is it more closely aligned - mercy or forgiveness?

Plainly, the legal pardon is distinct from both. It is not the equivalent of mercy because its upshot is not to sentence a guilty person to less than he deserves but to release an innocent person from the consequences of a punishment he never did deserve. Neither is it, as we have seen, like forgiveness because forgiveness is a moral response towards something which is blameworthy, not towards something which is blameless. 15

Yet there is a sense in which one could characterise the legal pardon as having more in common with the concept of mercy than the concept of forgiveness. One of the characteristics of mercy identified by Jeffrie Murphy and which, in his view, distinguishes it from forgiveness is the fact that mercy, once done, is done for all time and never needs to be repeated. ${ }^{16}$ In the same way, an individual can only ever be pardoned once in respect of any particular offence.

To conclude therefore, the legal pardon may be justified as a means of securing justice within the present criminal justice system with its inherent separation of powers. In this it possibly owes more to the concept of mercy than it does to forgiveness, although at the level of ordinary language these distinctions are sometimes blurred. Thus we may say that pardoning is part of the 'job' of secular authority, but is the same also true of mercy?

\section{Mercy}

First, to be clear about what mercy means. Writers dispute as to whether the word is capable of sustaining an autonomous meaning at all; but Jean Hampton has offered a definition which will serve for the purposes of this essay. She defines mercy as "the suspension or mitigation of a punishment which would otherwise be deserved

13. Ross Harrison, "The Equality of Mercy" supra n.l, passim.

14. Oxford English Dictionary, (Oxford, 1969).

15. Jean Hampton, "Forgiveness, Resentment and Hatred", supra n.4, p.40.

16. Jeffrie G. Murphy, "Forgiveness and Resentment", supra n.4, p.21. 
as retribution and which is granted out of pity and compassion for the wrongdoer." 17 It will be obvious that, in accepting this definition, we must narrow the range of our enquiry to the question of whether mercy can ever be the job, in part or in full, of a secular authority which subscribes to a retributivist theory of punishment. The question of whether mercy can be justified within a utilitarian system, whilst important, is not considered.

Mercy is different from forgiveness. Forgiveness is the adoption of a changed moral attitude towards the offender which may result in external action but which need not. Elizabeth Moberley points out that it is possible to forgive and still believe that the offender should suffer the full penalty. ${ }^{18}$ By contrast, mercy is an action: it must be demonstrated. It always involves treating the offender less harshly than he or she deserves. ${ }^{19}$

According to Murphy, one must have locus standi to forgive..$^{20}$ Thus Nigel Walker thinks it is necessary to distinguish between "interested" and "disinterested" forgiveness; that is, between the foregoing of personal resentment and the suppression of moral indignation. ${ }^{21}$ By the same token, we can say that one must also have locus standi to show mercy. Furthermore, standing to forgive, or to show mercy, is just as essential outside a legal system as within it. Thus, in the extra-legal world of private vendettas, for example, one can act mercifully by refraining from exacting revenge. Mercy and forgiveness do not just apply to offical punishment. But in relation to official punishment, it is hard to see how any secular authority could ever possess the necessary standing to forgive. 'Interested' forgiveness is the luxury of the victim and it is hard to characterise 'disinterested' forgiveness as true forgiveness. This leaves the question as to whether criminal justice officials possess the standing to show mercy and, if so, whether there are any grounds on which the display of mercy can be justified.

It is sometimes argued that mercy is not part of the métier of secular authority. Harrison, for example, argues that a State cannot act mercifully because "states ought to be purely rational entities"' 22 and should therefore treat relatively similar cases in similar ways. To act mercifully is, on his view, to act irrationally because the "normal rules of justice have to be suspended so that some people are specially treated." ${ }_{23}$ This is similar to the point made by Murphy that "temperings are tamperings" ${ }^{24}$ Secular authorities may not behave irrationally because this makes it impossible to enquire into and examine the reasons for action on the part of the State. There is thus no justification for mercy. In fact:

17. Jean Hampton, "The Retributive Idea" in Jeffrie G. Murphy and Jean Hampton, Forgiveness and Mercy (Cambridge, 1988), p. 158.

18. Elizabeth Moberley, Suffering, Innocent and Guilty (London, 1978), p. 136.

19. Jeffric G. Murphy, "Mercy and Legal Justice" in Jeffrie G. Murphy and Jean Hampton, Forgiveness and Mercy (Cambridge, 1988), p. 167.

20. Jeffrie G. Murphy, "Forgiveness and Resentment" supra n.4, p.21.

21. Nigel Walker, Why Punish? (Oxford, 1991), p.115.

22. Ross Harrison, "The Equality of Mercy", in Hyman Gross and Ross Harrison, Jurisprudence: Cambridge Essays, (Oxford, 1992), p.107.

23. Ibid., p. 108 .

24. Jeffrie G. Murphy, "Mercy and Legal Justice", supra n.19, p.167. 
“only by forgoing mercy can we enable the State . . to behave like a fully rational entity, accountable for all its actions to the people over whom it has power." 25

Harrison admits that this conclusion is "highly counter-intuitive." 26 It certainly is. It is not counter-intuitive to claim that the State should not act arbitrarily or irrationally but it is counter-intuitive to claim that the State has no opportunities for acting mercifully. Perhaps the reason why his conclusion seems to be counter-intuitive is because his conception of mercy is itself flawed. His definition does not seem to go beyond the statement that mercy is something which is irrational and that one can never therefore have a reason for acting in a merciful way. On this view, naturally enough, reason "squeezes out" mercy. ${ }^{27}$ Yet this seems to be an excessively minimal definition.

Hampton's definition of mercy, above, is much more intuitive. However, it is not a wholly rational one. In reflecting something of mercy's claim to be a moral virtue, her definition explicitly recognises that the suspension or mitigation of punishment is motivated by feelings of compassion or pity.

Some writers have tried to take a less emotional view. Alwynne Smart, for example, characterises mercy as something which we call in aid when we are "compelled" 28 to treat an offender less harshly than he deserves as a result of "the claims that other obligations have on us." '29 According to Smart an example of such an obligation would include the suffering which might be caused to an innocent party as a result of his receiving the full penalty. ${ }^{30}$ Where this suffering is so great as to be "a major, even the main consideration" 31 a judge might be expected to show mercy.

However such a definition, which would reduce mercy to a means of "resolving conflicts of duties"'32 seems to fall rather short. Although Smart does grant that mercy is motivated by feelings of benevolence ${ }^{33}$ something stronger is required, namely that element of compassion or pity which enables one to empathise with the offender.

Thus the concept of mercy presents a dilemma. Rational definitions of mercy seem unconvincing and minimalistic whilst more intuitive definitions seem to lead to the conclusion that mercy and retributive justice are irreconcilable.

However it will be argued that mercy is properly the métier of secular authority. Using Hampton's definition, this reasoning accepts that there will always be a sense

25. Ross Harrison, 'The Equality of Mercy, supra n.22, p.118.

26. lbid., p. 118 .

27. Ibid., p. 122 .

28. Alwynne Smart, "Mercy" in H.B. Acton (ed.) The Philosophy of Punishment (London, 1969), p.227.

29. Ibid., p.227.

30. Ibid., p.222.

31. Ibid., p.222.

32. Nigel Walker, supra n.21, p.116.

33. Alwynne Smart, "Mercy", supra n.28, p.227 
in which the practice of mercy by the State is irrational, but suggests that its application by the courts need not be arbitrary.

Most writers accept that it is possible to justify mercy at the level of the individual. This is what Murphy calls the "private law paradigm" 34 the reason presumably being that individuals cannot show mercy in matters relating to the criminal law since only the State has the power to punish. An individual may wish to show mercy because he has sympathy with the wrongdoer and can see no reason not to treat the wrongdoer in a manner which he himself would want to be treated. Plainly the circumstances in which mercy is shown, as well as its degree, are not rationally determined. This is not a problem because the individual is under no obligation to act consistently. Murphy tries to justify differential treatment on the grounds that the relevant distinction between the treatment given to, for example, Jones and Smith is not some feature that distinguishes Jones from Smith but rather some feature that distinguishes the impact, on the individual, of mercy to Jones from the impact, on the individual, of mercy to Smith. But there is really no need for this. As Harrison points out irrationality on this level can always be justified on the basis of respect for individual autonomy. ${ }^{35}$

It is sometimes argued that what is justifiable for individuals, operating within the civil law paradigm, is not justifiable for the State operating within the criminal law paradigm. Murphy rebuffs this argument by reasoning that:

"If each citizen can show mercy individually when his individual interests are at issue, why may not all citizens justly join together and exercise mercy collectively when their collective interests are at issue?"'36

He suggests that the individual's power to exercise mercy could be delegated to the judiciary and that this power could be exercised whenever the judiciary "believes" that the public "unanimously" so wishes them to act. ${ }^{37}$ The criteria for a valid belief are not outlined, but Murphy seems to suggest that within this formula mercy could play a significant role. The proviso does not, for example, require the judge to be sure of the general will.

As a justification for the exercise of mercy by the State it raises practical difficulties but it is theoretically attractive. It highlights the shortcomings of Harrison's argument which relies too much on a polarised distinction between the State and the individual. Murphy's formula recognises that actions on the part of the State are willed by individuals acting, notionally at any rate, on behalf of members of the State. Murphy's justification also obviates the danger, often cited as a criticism of mercy, that:

34. Jeffrie G. Murphy, "Mercy and Legal Justice", supra n. 19, p.175.

35. Ross Harrison, "The Equality of Mercy", supra n.22, pp.117-8.

36. Jeffrie G. Murphy, "Mercy and Legal Justice", supra n.19, p.178.

37. Ibid., p. 178 . 
"the judge who is influenced simply by the plight of the offender before him may lose sight of the fact that his job is to uphold an entire system of justice that protects the security of all citizens." 38

By contrast, under Murphy's justification the judge, or other secular official, is not acting on his own sentiments but "as a vehicle for expressing the sentiments of all those who have been victimised by the criminal." 39 That there should be provision, at the leve! of the State, for individuals to express collectively the individual desire for mercy is justifiable because it is only the State which, for good reason, has the capacity to punish for criminal offences.

There remains, however, one major sense in which the delegated capacity of the State to act mercifully can be distinguished from the individual capacity to act mercifully. Whereas the individual does not have to behave consistently, the State must because it speaks with one voice. Where it does not, the act of mercy may not be justified. As Murphy notes, "once a reason, always a reason." 40

The difficulty lies in articulating some compassionate grounds for showing mercy which can be consistently applied. If the grounds are not compassionate, then it is hard to distinguish mercy from mere extenuating reasons, such as provocation or duress. On the other hand, the need for compassion might itself seem to preclude the need for consistency.

One approach might be to limit mercy to a specific class of persons, perhaps along the lines of the Italian practice of showing mercy to pregnant women. This approach, 'class mercy', is similar to the way in which the prerogative of mercy has functioned historically in English law. As Walker sees it, the purpose of this has been to introduce new 'class' or 'group' reasons for lessening punishment. In the past such groups included juveniles and infanticidal mothers. ${ }^{41}$ Consistent compassion leads to consistent innovation. "Any penal system which still has . . points of rigidity needs a device of this kind." 42

However, 'class mercy' suffers from the problem of reducing the deterrent effect of punishment among the particular group or class.

Thus, a better solution might be provided by the Benthamite idea of 'sensibility'. ${ }^{43}$ This acknowledges that some offenders, depending on demographic and social factors and perhaps even on the circumstances of the case, are more sensitive to punishment than others. This formula, like the others, is compassionate and can be consistently applied; yet unlike the others, it has the advantage of leaving it up to the court to decide who is a member of the class. It is also wide enough to cover the wide variety of cases which are presented in the literature as requiring mercy. ${ }^{44}$

38. Ibid., p. 168.

39. Ibid., p. 179 .

40. Ibid., p. 181.

41. Nigel Walker, supra n.21, p.117.

42. Ibid., p.117.

43. Jeremy Bentham, Introduction to the Principles of Morals and of Legislation (London, 1798).

44. See Alwynne Smart, "Mercy", supra n.28, pp. 212-227 for some interesting examples. 
In conclusion, mercy on the part of some secular authority may be justified on the ground that it is exercising the delegated capacity of individuals to act mercifully. The State has standing to show mercy but must always act consistently in doing so. The situations in which mercy is exercised as well as its degree cannot be defended on purely rational grounds. That would negate the element of compassion which is part of any meaningful definition of mercy. However, it should be possible for the State to act with both consistency and compassion. Thus mercy is not "reasoned leniency," 45 nor is it a right for its basis lies outside the law. Yet it is not beyond the scope of rules. As a result, mercy does not collapse into injustice because to act mercifully need not involve acting in a way that is arbitrary or capricious.

45. Nigel Walker, supra n.21, p.115. 